\title{
Anaerobic degradation of toluene by pure cultures of denitrifying bacteria
}

\author{
Riet J. Schocher, Birgit Seyfried, Francisco Vazquez, and Josef Zeyer \\ Swiss Federal Institute for Water Resources and Water Pollution Control (EAWAG/ETH), CH-6047 Kastanienbaum, Switzerland
}

Received July 11, 1991/Accepted August 12, 199 .

\begin{abstract}
Several denitrifying Pseudomonas spp., isolated with various aromatic compounds, were tested for the ability to degrade toluene in the absence of molecular oxygen. Four out of seven strains were able to degrade toluene in the presence of $\mathrm{N}_{2} \mathrm{O}$. More than $50 \%$ of the ${ }^{14} \mathrm{C}$ from ring-labelled toluene was released as $\mathrm{CO}_{2}$, and up to $37 \%$ was assimilated into cell material. Furthermore it was demonstrated for two strains that they were able to grow on toluene as the sole carbon and energy source in the presence of $\mathrm{N}_{2} \mathrm{O}$. Suspensions of cells pregrown on toluene degraded toluene, benzaldehyde or benzoate without a lag phase and without accumulation of intermediates. $p$-Cresol, $p$-hydroxybenzylalcohol, $p$ hydroxybenzaldehyde or $p$-hydroxybenzoate was degraded much slower or only after distinct lag times. In the presence of fluoroacetate $\left[{ }^{14} \mathrm{C}\right]$ toluene was transformed to $\left[{ }^{14} \mathrm{C}\right]$ benzoate, which suggests that anaerobic toluene degradation proceeds through oxidation of the methyl side chain to benzoate.
\end{abstract}

Key words: Pseudomonas spp. - Toluene - Aromatic hydrocarbons - Anaerobic degradation

Toluene is a major product of the petrochemical industry, and its global production exceeds 10 million tons per year (Fishbein 1985). Due to its widespread use, toluene is an ubiquitous pollutant, 'and it can be detected in almost every environmental compartment.

Microbial degradation of toluene under aerobic conditions is well documented (Gibson and Subramanian 1984). The initial catabolic step is reportedly catalyzed by oxygenases and hence requires molecular oxygen as a cosubstrate. Nevertheless, the anaerobic degradation of toluene has been demonstrated in mixed cultures under denitrifying or methanogenic conditions (Kuhn et al.

Offprint requests to: $\mathrm{J}$. Zeyer
1985, 1988; Wilson et al. 1986; Zeyer et al, 1986; GrbićGalić and Vogel 1987; Evans et al. 1991 a) and in pure microbial cultures under denitrifying or iron reducing conditions (Lovley and Lonergan 1990; Dolfing et al. 1990; Evans et al. 1991 b).

Potential catabolic steps to initiate anaerobic toluene degradation include (Fig. 1): i) oxidation of the methyl group, ii) hydroxylation of the aromatic nucleus or iii) carboxylation of the aromatic nucleus. To date, only poor evidence to suggest a particular pathway exists.

In this study we show that toluene can be degraded under pure culture conditions by several denitrifying microorganisms. Furthermore, we present data suggesting a direct oxidation of the methyl side chain of toluene under anaerobic conditions.

\section{Materials and methods}

\section{Chemicals}

Benzaldehyde and benzoic acid were purchased from Merck (Darmstadt, FRG). Toluene, p-cresol, $p$-hydroxybenzylalcohol, $p$-hydroxybenzaldehyde, sodium $p$-hydroxybenzoate, benzylalcohol, $o-, m$ - and $p$-toluic acid, sodium pyruvate and sodium fluoroacetate were obtained from Fluka AG (Buchs, Switzerland). All chemicals were of the highest available purity and were used as received. [Ring-UL- ${ }^{14} \mathrm{C}$ ] toluene (specific activity $10.9 \mathrm{mCi} \mathrm{mmol}^{-1}$ ) and $\left[\right.$ methyl- $\left.{ }^{14} \mathrm{C}\right]$ toluene (specific activity $8.6 \mathrm{mCi} \mathrm{mmol}^{-1}$ ) were purchased from Pathfinder Laboratories Inc. (St. Louis, Mo., USA), and $\left[{ }^{14} \mathrm{C}\right] \mathrm{NaHCO}_{3}$ (specific activity $54.1 \mathrm{mCi} \mathrm{mmol}{ }^{-1}$ ) was obtained from Amersham International plc (Amersham, UK). Purity of radiochemicals was greater than $98 \%$ according to the supplier. $\mathrm{N}_{2}(>99.999 \%)$ and $\mathrm{N}_{2} \mathrm{O}(>99.9 \%)$ were obtained from PanGas (Lucerne, Switzerland).

\section{Organisms, media and growth conditions}

The denitrifying microorganisms used throughout this study were enriched, isolated, and cultivated as previously reported (Table 1, Tschech and Fuchs 1987; Dolfing et al. 1990; Seyfried et al. 1991). For strain T, the basal medium described by Dolfing et al. (1990) was slightly modified: The $\mathrm{pH}$ was adjusted to 7.8 and, to avoid 
Table 1. Origin of organisms

\begin{tabular}{|c|c|c|c|}
\hline Strain $^{\mathrm{a}}$ & Source & $\begin{array}{l}\text { Substrate used } \\
\text { for enrichment and } \\
\text { isolation }\end{array}$ & Reference \\
\hline $\mathrm{T}$ & Anaerobic laboratory aquifer column & Toluene & Dolfing et al. 1990 \\
\hline K 172 & Anaerobic sludge from a municipal sewage plant & Phenol & Tschech and Fuchs 1987 \\
\hline S 100 & Anaerobic sediment samples from a polluted creek & Phenol & Tschech and Fuchs 1987 \\
\hline S2 & Anaerobic sediment samples from a polluted creek & Salicylate & Seyfried et al. 1991 \\
\hline SP & Anaerobic sediment samples from a polluted creek & Phenylacetate & Seyfried et al. 1991 \\
\hline B4P & Aerobic activated sludge from a municipal sewage plant & $p$-Hydroxyphenylacetate & Seyfried et al. 1991 \\
\hline FF & Aerobic agricultural soil & Phenylalanine & Seyfried, unpublished \\
\hline
\end{tabular}

all strains were tentatively identified as Pseudomonas spp.

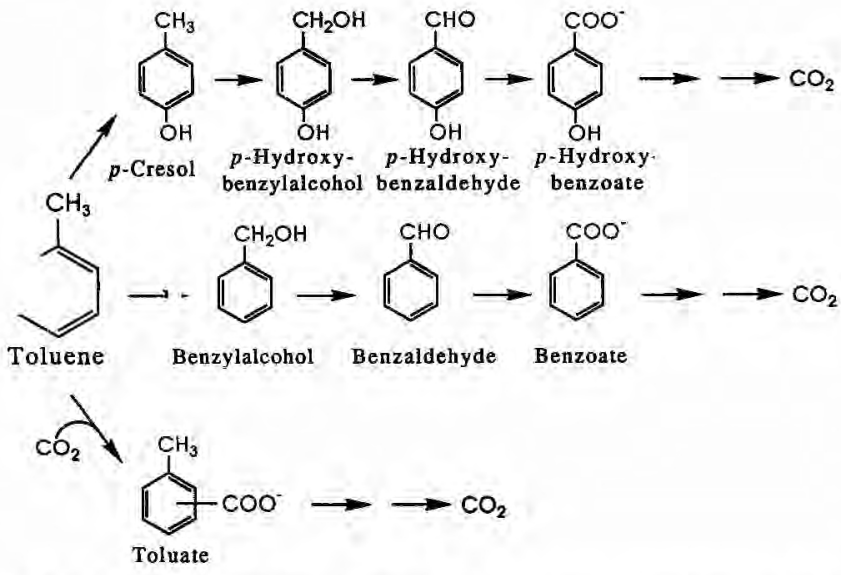

Fig. 1. Postulated pathways of anaerobic toluene degradation. Pathways are based on suggestions presented by Grbić-Galić and Vogel (1987); Kuhn et al. (1988); Tschech and Fuchs (1989); Lovley and Lonergan (1990) and Schnell and Schink (1991)

precipitation, $\mathrm{CaCl}_{2} \times 2 \mathrm{H}_{2} \mathrm{O}$ and $\mathrm{MgSO}_{4} \times 7 \mathrm{H}_{2} \mathrm{O}$ were added aseptically from concentrated stock solutions after autoclaving. For all other strains the basal medium described by Tschech and Fuchs (1987) was used. Autoclaved media were cooled under a flux of $\mathrm{N}_{2}$. Aliquots $(25 \mathrm{ml}$ to 11$)$ were aseptically transferred to sterile serum bottles ( $50 \mathrm{ml}$ to $2 \mathrm{l}$ ), gassed with $\mathrm{N}_{2}$, and sealed with butyl rubber stoppers (Bellco Glass, Vineland, N.J,, USA). Media were purged with $\mathrm{N}_{2} \mathrm{O}$ prior to inoculation and incubated under a $\mathrm{N}_{2} \mathrm{O}$ headspace. Unless stated otherwise toluene was added as pure liquid by microsyringe to yield a theoretical concentration of $1 \mathrm{mM}$ in the medium. However the actual concentration in the medium was 0.3 to $0.6 \mathrm{mM}$, since 15 to $60 \%$ of the added toluene sorbed to the butyl rubber stoppers (depending on the batch and the age of the stoppers), and 10 to $20 \%$ remained in the headspace. During growth on toluene it slowly desorbed from the stoppers. Therefore the toluene concentrations indicated in this study always refer to a theoretical concentration in the medium. Liquid cultures were incubated at $30^{\circ} \mathrm{C}$ on a rotary shaker in the dark. Growth was followed by measuring the optical density at $546 \mathrm{~nm}\left(\mathrm{OD}_{546}\right)$. For experiments with concentrated cell suspensions and for $\left[{ }^{14} \mathrm{C}\right]$ carbon balance studies toluene was added from concentrated stock solutions prepared in ethanol (strain T) or methanol (all other strains), respectively.

Strain $\mathrm{T}$ was maintained anaerobically on agar slants $(5 \mathrm{ml}$ basal medium $+2 \%$ agar $+2 \mu$ l toluene) under a $\mathrm{N}_{2} \mathrm{O}$-headspace in tubes sealed with butyl rubber stoppers. Liquid inocula of strain $\mathrm{T}$ were prepared by overlaying the agar slants with $10 \mathrm{ml}$ basal medium and incubating the suspension for one day. All other strains were subcultured anaerobically in basal medium supplemented with phenol (1 mM; strains K 172, S 100, SP and S2) or p-hydroxyphenylacetate $(1 \mathrm{mM}$; strains B4P and FF) plus nitrate (4 or $4.5 \mathrm{mM}$, respectively). For long-term storage liquid cultures $(5 \mathrm{ml})$ at an $\mathrm{OD}_{546}$ of 0.5 to 1.0 were supplemented with $5 \%$ sterile glycerol and kept at $-20^{\circ} \mathrm{C}$.

\section{Catabolic studies with cell suspensions}

Cultures were grown on basal medium supplemented with toluene and $\mathrm{N}_{2} \mathrm{O}$. The cultures were repeatedly fed with $1 \mathrm{mM}$ toluene, harvested at an $\mathrm{OD}_{546}$ of 0.6 to 0.7 by centrifugation $(10 \mathrm{~min}$, $10000 \times g, 4^{\circ} \mathrm{C}$ ) and washed once with basal medium. Cell pellets were resuspended in basal medium to an $\mathrm{OD}_{546}$ of 10 to 15 . The suspension was made oxygen-free by purging it with $\mathrm{N}_{2} \mathrm{O}$ for $30 \mathrm{~min}$ at $4^{\circ} \mathrm{C}$. Subsequently, it was supplemented with $0.5 \mathrm{mM}$ toluene and incubated at $30^{\circ} \mathrm{C}$ to restore full activity. The change in toluene concentration was measured by gas chromatography (GC). After depletion of toluene, aliquots $(5-20 \mathrm{ml})$ of the cell suspension were transferred by syringe to $\mathrm{N}_{2} \mathrm{O}$-filled serum bottles sealed with butyl rubber stoppers. Substrates were added from concentrated anaerobic stock solutions to an initial concentration of $1 \mathrm{mM}$ and the suspensions were incubated at $30^{\circ} \mathrm{C}$. Samples were withdrawn every 15 to 30 min and analyzed by GC or high pressure liquid chromatography (HPLC).

\section{Analytical methods}

Protein was determined by the method of Lowry modified according to Herbert et al. (1971) with bovine serum albumin as the standard. Dry weight was determined by drying cell pellets at $80^{\circ} \mathrm{C}$ until reaching constant weight.

Toluene was assayed by GC as described previously (Kuhn et al. 1988). Other aromatic compounds were analyzed by HPLC under isocratic conditions with a LiChroCART 125-4, RP18-column (Merck). The mobile phase consisted of aqueous ammonium phosphate buffer $(100 \mathrm{mM}, \mathrm{pH} 3.2)$-methanol-water $(10: 45: 45, \mathrm{v} / \mathrm{v} / \mathrm{v})$, the flow rate was $1 \mathrm{ml} \cdot \mathrm{min}^{-1}$. Detection was at $260 \mathrm{~nm}$. The detection limit of aromatic compounds was $0.005 \mathrm{mM}$. Prior to injection, samples of cultures or cell suspensions were treated with perchloric acid (final concentration $0.3 \mathrm{mM}$ ) and centrifuged to precipitate cells and proteins.

Carbon balance studies using $\left[{ }^{14} \mathrm{C}\right]$ toluene as a substrate were performed as previously described (Dolfing et al. 1990). At the end of the incubation, the cultures were acidified to $\mathrm{pH} 2$ and purged with air. Toluene and $\mathrm{CO}_{2}$ were trapped in isobutanol and $0.1 \mathrm{~N}$ $\mathrm{NaOH}$, respectively, and the radioactivity sorbed by the butyl rubber stopper (presumed to be toluene) was determined after extraction with ethyl acetate. Quantification of radioactivity was performed by liquid scintillation counting.

The separation of ${ }^{14} \mathrm{C}$-benzoate accumulated in cell suspensions treated with fluoroacetate was performed by thin layer chroma- 
Table 2. Degradation of [ring-UL- $\left.{ }^{14} \mathrm{C}\right]$ toluene by various Pseudomonas spp. in presence of $\mathrm{N}_{2} \mathrm{O}$ as sole electron acceptor

\begin{tabular}{|c|c|c|c|c|c|}
\hline \multirow[t]{2}{*}{ Strain } & \multicolumn{5}{|c|}{${ }^{14} \mathrm{C}$ Balance after an incubation time of 2 weeks ( $\%$ ) } \\
\hline & $\begin{array}{l}{\left[{ }^{14} \mathrm{C}\right] \text { Toluene recovered }} \\
\text { from culture }\end{array}$ & ${ }^{14} \mathrm{CO}_{2}$ evolved & $\begin{array}{l}{ }^{14} \mathrm{C} \text {-labeled residues } \\
\text { remaining in culture }\end{array}$ & $\begin{array}{l}{\left[{ }^{14} \mathrm{C}\right] \text { Toluene sorbed }} \\
\text { to stopper }\end{array}$ & Total ${ }^{14} \mathrm{C}$ recovery \\
\hline $\mathrm{T}$ & $<1$ & 50 & 17 & 21 & 88 \\
\hline K 172 & $<1$ & 52 & 27 & 6 & 85 \\
\hline S 100 & $<1$ & 45 & 37 & 7 & 89 \\
\hline $\mathrm{S} 2$ & $<1$ & 54 & 23 & 4 & 81 \\
\hline Sterile control & 16 & $<1$ & $<1$ & 67 & 83 \\
\hline
\end{tabular}

The strains were incubated on basal medium plus $0.3 \mathrm{mM}\left[\right.$ ring-UL- $\left.{ }^{14} \mathrm{C}\right]$ toluene. The medium was supplemented with $5 \mathrm{mM}$ pyruvate (strail $\mathrm{T}$ and sterile control) or $0.5 \mathrm{mM}$ benzoate (all other strains). The data represent average values of at least 2 independent determinations

tography (TLC). The cell suspensions were acidified to $\mathrm{pH} 2$ and purged as described above. The remaining medium was centrifuged $(10 \mathrm{~min}, 10000 \times \mathrm{g})$ and the supernatant was extracted with diethyl ether. The extract was concentrated and applied to a TLC plate coated with silica gel $60 \mathrm{~F}_{254}$ (layer thickness $0.25 \mathrm{~mm}$; Merck). The TLC plates were developed with $p$-xylene-methanol-acidic acid $(90: 20: 8, \mathrm{v} / \mathrm{v} / \mathrm{v})$. Benzoate (retention factor 0.44$)$ was located either by UV light or by spraying reference plates with 2,6-dinitrophenolindophenol $\left[0.1 \%(\mathrm{v} / \mathrm{v})\right.$ in ethanol] followed by heating $\left(100^{\circ} \mathrm{C}\right.$, $5 \mathrm{~min}$ ). For quantification of benzoate silica gel containing benzoate was scraped off from nonsprayed plates and eluted with methanol. The amount of benzoate in the solution was determined by HPLC, and the radioactivity was quantified by liquid scintillation counting,

\section{Results}

\section{Degradation of toluene by various Pseudomonas spp}

Pseudomonas sp. strain $\mathrm{T}$, which was isolated from a denitrifying, toluene-degrading, laboratory aquifer column (Dolfing et al. 1990), mineralized toluene with $\mathrm{N}_{2} \mathrm{O}$ as the sole electron acceptor (Table 2). In addition, however, three Pseudomonas spp. which were enriched and isolated on phenol (strain K 172 and strain S 100) or salicylate (strain S2) were also able to degrade toluene in presence of $\mathrm{N}_{2} \mathrm{O}$ (Table 2). More than $45 \%{ }^{14} \mathrm{CO}_{2}$ was formed from [ring-UL- $\left.{ }^{14} \mathrm{C}\right]$ toluene and up to $37 \%$ carbon was assimilated into cell material. Three Pseudomonas spp., enriched and isolated on phenylacetate (strain SP), $p$-hydroxyphenylacetate (strain B4P) or phenylalanine (strain FF), were unable to mineralize toluene in presence of $\mathrm{N}_{2} \mathrm{O}$. Strain $\mathrm{SP}$ has been described to grow on toluene under denitrifying conditions (Seyfried et al. 1991), but meanwhile it has lost this ability.

Besides $\mathrm{N}_{2} \mathrm{O}$ also nitrate $(5 \mathrm{mM})$ served as electron acceptor during growth on toluene, but growth was inhibited by the transient accumulation of nearly stoichiometric amounts of nitrite (data not shown). Strains K $172, \mathrm{~S} 100$ and $\mathrm{S} 2$ did not grow on toluene in the presence of oxygen as electron acceptor, while strain T could grow aerobically on toluene.

Toluene degradation by strain $\mathrm{T}$ and strain $\mathrm{K} 172$ was examined in more detail. Both strains were able to grow on toluene as sole source of carbon and energy in presence of $\mathrm{N}_{2} \mathrm{O}$ as the sole electron acceptor (Figs. 2 and 3). The generation times (usually between 7 and $20 \mathrm{~h}$ ) varied

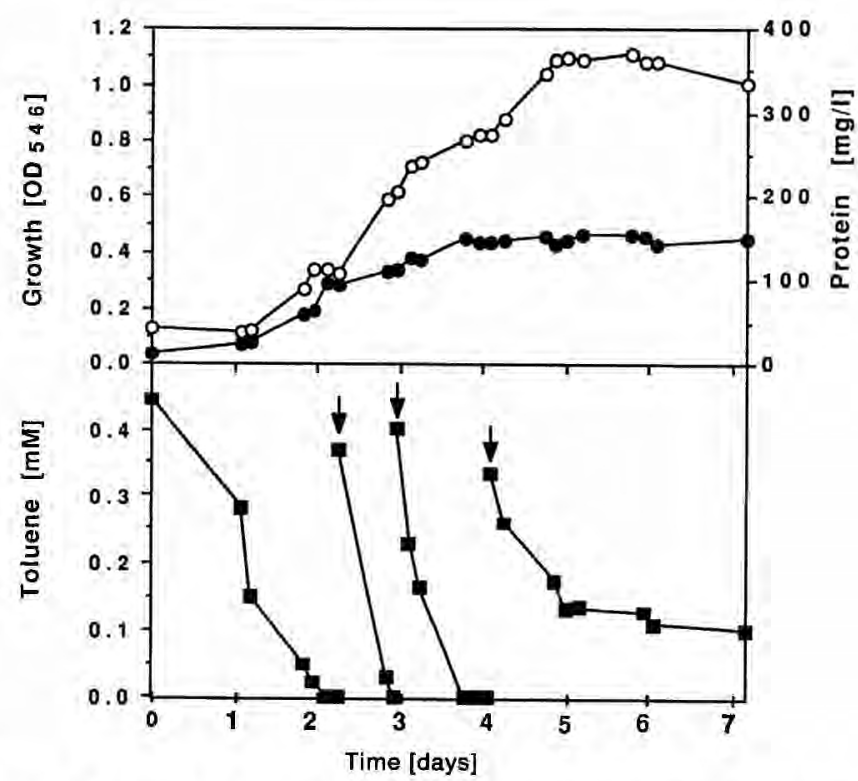

Fig. 2. Growth of strain $\mathrm{T}$ in basal medium plus $1 \mathrm{mM}$ toluene and a. $\mathrm{N}_{2} \mathrm{O}$-headspace. toluene, protein, $\bigcirc \mathrm{OD}_{546}, \downarrow$ addition of $1 \mathrm{mM}$ toluene

strongly from batch to batch. The molar growth yield (g dry matter formed per mole substrate consumed) with toluene and $\mathrm{N}_{2} \mathrm{O}$ was $60 \mathrm{~g}$ per mole for strain $\mathrm{T}$ and $49 \mathrm{~g}$ per mole for strain K 172 .

Based on the data presented in Figs. 2 and 3, the specific activity of toluene degradation was calculated to be in the order of 5 to $12 \mu \mathrm{mol} \cdot \mathrm{min}^{-1} \cdot \mathrm{g}^{-1}$ protein for strain $\mathrm{T}$ and 20 to $50 \mu \mathrm{mol} \cdot \mathrm{min}^{-1} \cdot \mathrm{g}^{-1}$ protein for strain K 172.

\section{Growth of strain T and strain K 172 on potential intermediates of the anaerobic toluene degradation}

Various compounds were postulated to be intermediates of the anaerobic toluene degradation (Grbić-Galić and Vogel 1987; Kuhn et al. 1988; Lovley and Lonergan 1990). Growth of strain $T$ and strain K 172 on these compounds is shown in Table 3. Toluene, benzaldehyde, benzoate, $p$-hydroxybenzaldehyde, and $p$-hydroxybenzoate served as growth substrates for both strains. Benzylalcohol and p-hydroxybenzylalcohol only sup- 


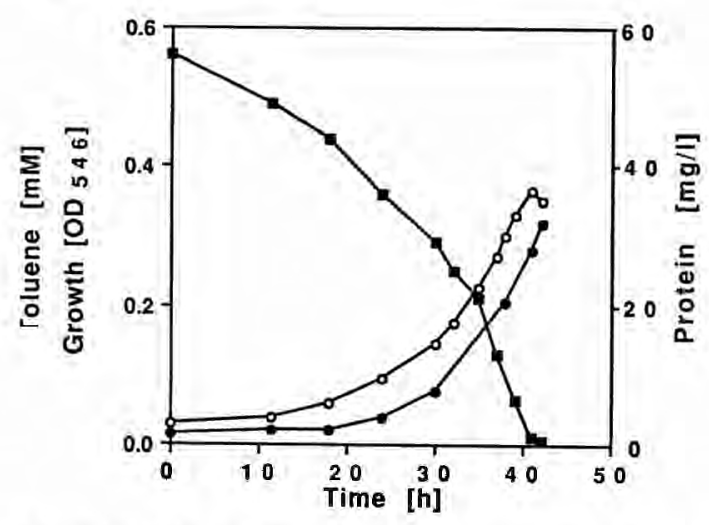

Fig. 3. Growth of strain $\mathrm{K} 172$ in basal medium plus $1 \mathrm{mM}$ toluene and a $\mathrm{N}_{2} \mathrm{O}$-headspace. toluene, protein, $\mathrm{O} \mathrm{OD}_{546}$

Table 3. Growth of strain T and strain K 172 on potential intermediates of the anaerobic toluene degradation

\begin{tabular}{lll}
\hline Substrate & Strain T & Strain K 172 \\
\hline Toluene & + & + \\
Benzylalcohol & - & + \\
Benzaldehyde & + & + \\
Benzoate & + & + \\
$o$-Toluate & - & - \\
$m$-Toluate & \pm & - \\
$p$-Toluate & - & + \\
$p$-Cresol & + & + \\
$p$-OH-Benzylalcohol & - & + \\
$p$-OH-Benzaldehyde & + & + \\
$p$-OH-Benzoate & + & + \\
\hline
\end{tabular}

Growth was determined on basal medium plus $1 \mathrm{mM}$ substrate under a $\mathrm{N}_{2} \mathrm{O}$-headspace; + significant turbidity $\left(\mathrm{OD}_{546}>0.1\right)$, - no growth, \pm poor growth, not reproducible

ported growth of strain $\mathrm{K} 172$, and $o$ - or $p$-toluate were utilized neither by strain T nor by strain K 172 .

\section{Degradation of potential intermediates of the anaerobic toluene degradation by cell suspensions}

Suspensions of cells precultured on toluene were able to degrade or transform a number of potential intermediates of the anaerobic toluene degradation (Table 4). Suspensions of strain $T$ utilized all of the substrates tested with the exception of benzylalcohol. Although $p$-cresol and $p$-hydroxybenzylalcohol were degraded without lag phases the initial activity was about two times lower than that of toluene degradation. $p$-Cresol, $p$-hydroxybenzylalcohol or $p$-hydroxybenzaldehyde were transformed almost stoichiometrically to $p$-hydroxybenzoate; the latter was degraded only after a lag phase of $60 \mathrm{~min}$. Suspensions of strain K 172 showed a similar activity pattern as strain $\mathrm{T}$, except for degradation of $p$-cresol and $p$ hydroxybenzylalcohol (Table 4). With $p$-cresol as substrate no accumulation of $p$-hydroxybenzoate could be detected. $p$-Hydroxybenzylalcohol was transformed only after $45 \mathrm{~min}$ and the lag time for $p$-hydroxybenzoate
Table 4. Degradation of potential intermediates by suspensions of cells precultured on toluene

\begin{tabular}{|c|c|c|}
\hline \multirow[t]{2}{*}{ Substrate $^{\mathrm{a}}$} & \multicolumn{2}{|c|}{$\begin{array}{l}\text { Initial activity } \\
{\left[\mu \mathrm{mol} \cdot \min ^{-1} \cdot \mathrm{g}^{-1} \text { protein }\right]}\end{array}$} \\
\hline & Strain $\mathrm{T}$ & Strain K 172 \\
\hline Toluene & 8 & 14 \\
\hline Benzylalcohol & $<1$ & $<1$ \\
\hline Benzaldehyde & $>30$ & 23 \\
\hline Benzoate & 11 & 18 \\
\hline$p$-Cresol & 3 & 8 \\
\hline$p$-Hydroxybenzylalcohol & 5 & $<1^{b}$ \\
\hline$p$-Hydroxybenzaldehyde & $>30$ & 9 \\
\hline$p$-Hydroxybenzoate & $<1^{b}$ & $<1^{b}$ \\
\hline
\end{tabular}

a Substrates were added to give an initial concentration of $1 \mathrm{mM}$.

b Turnover started only after $60 \mathrm{~min}$ ( $p$-hydroxybenzoate, strain $\mathrm{T}), 45 \mathrm{~min}$ ( $p$-hydroxybenzylalcohol, strain $\mathrm{K} \mathrm{172)}$ or $30 \mathrm{~min}(p$ hydroxybenzoate, strain $\mathrm{K} 172$ )

Table 5. Accumulation of intermediates by cell suspensions incubated in presence of fluoroacetate and toluene or $p$-cresol

\begin{tabular}{|c|c|c|c|c|}
\hline \multirow[t]{3}{*}{ Substrate } & \multicolumn{4}{|c|}{ Intermediates accumulated after $2 \mathrm{~h}$ [mM] } \\
\hline & \multicolumn{2}{|l|}{ Strain T } & \multicolumn{2}{|c|}{ Strain K 172} \\
\hline & Benzoate & $\begin{array}{l}p \text {-Hydroxy. } \\
\text { benzoate }\end{array}$ & Benzoate & $\begin{array}{l}p \text {-Hydroxy. } \\
\text { benzoate }\end{array}$ \\
\hline Toluene & 0.16 & n.d. & 0.15 & n.d. \\
\hline$p$-Cresol & n.d. & 0.45 & 0.04 & 0.15 \\
\hline
\end{tabular}

Cells were pre-cultured on toluene and the suspensions were incubated in presence of $1 \mathrm{mM}$ toluene and $1 \mathrm{mM}$ p-cresol, respectively, under a $\mathrm{N}_{2} \mathrm{O}$-headspace. Fluoroacetate was supplied at a concen-

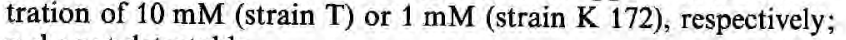
n.d.: not detectable

degradation was $30 \mathrm{~min}$. The degradation of the benzaldehydes was slower than by cell suspensions of strain $\mathrm{T}$.

Suspensions of cells of strain T pregrown on pyruvate rapidly transformed the benzaldehydes to their corresponding acids $\left(30 \mu \mathrm{mol} \cdot \mathrm{min}^{-1} \cdot \mathrm{g}^{-1}\right.$ protein). However all other compounds listed in Table 4 were not degraded or transformed in these suspensions within $2 \mathrm{~h}$ (data not shown).

\section{Accumulation of intermediates \\ of the anaerabic p-cresol and toluene degradation}

In growing cultures and cell suspensions of strain $\mathrm{T}$ and strain K 172 degrading toluene no intermediates could be detected in the medium by HPLC- or GC-analysis. However, cell suspensions incubated in presence of toluene and fluoroacetate, a known inhibitor of the tricarboxylic acid cycle, accumulated benzoate, whereas with $p$-cresol as the substrate $p$-hydroxybenzoate accumulated (Table 5). 
Table 6. Accumulation of $\Gamma^{19} \mathrm{C}$ bernzoate by cell suspensions inicis bated in presence of $\left({ }^{14} \mathrm{C}\right]$ toluene and fluoroacetate

\begin{tabular}{llcc}
\hline & $\begin{array}{l}\text { Specific } \\
\text { activity of } \\
\text { toluene added } \\
{\left[10^{3} \mathrm{dpm}\right.} \\
\left.\mu \mathrm{mol}^{-1}\right]\end{array}$ & $\begin{array}{l}\text { Specific activity of } \\
\text { benzoate recovered } \\
{\left[10^{3} \mathrm{dpm} \mu \mathrm{mol}^{-1}\right]}\end{array}$ \\
\cline { 3 - 4 } & Strain T & Strain $\mathrm{K} 172$ \\
\hline$\left[\right.$ Ring-UL- $\left.{ }^{14} \mathrm{C}\right]$ toluene & 9.5 & 9.4 & 9.5 \\
{$\left[\right.$ Methyl- $\left.{ }^{14} \mathrm{C}\right]$ toluene } & 12.9 & 11.1 & 13.4 \\
Toluene $+{ }^{14} \mathrm{CO}_{2}$ & n.a. & 0.1 & $<0.1$
\end{tabular}

Experimental conditions were analogous to those described in Table 5, however toluene was replaced by $\left[{ }^{14} \mathrm{C}\right]$ toluene; n.a.: not applicable; specific activity of carbonate in the assay was calculated to be $11 \cdot 10^{3} \mathrm{dpm} \mu \mathrm{mol}^{-1}$ at the end of the incubation

In order to determine whether benzoate was a true intermediate of the anaerobic toluene degradation, catabolic studies using $\left[{ }^{14} \mathrm{C}\right]$ toluene were performed. The results presented in Table 6 demonstrate that degradation of $\left[{ }^{14} \mathrm{C}\right]$ toluene in presence of fluoroacetate led to the accumulation of $\left[{ }^{14} \mathrm{C}\right]$ benzoate. The specific radioactivities of the substrate (toluene) and the intermediate (benzoate) were identical. As shown by using $\left[\right.$ methyl $\left.-{ }^{14} \mathrm{C}\right]$ toluene, the carboxyl group of benzoate was fully derived from the methyl side chain of toluene. Degradation of unlabelled toluene in presence of fluoroacetate and ${ }^{14} \mathrm{CO}_{2}$ did not lead to the accumulation of $\left[{ }^{14} \mathrm{C}\right]$ benzoate.

\section{Discussion}

Various Pseudomonas spp. were able to degrade toluene under denitrifying conditions, although they were isolated with different aromatic compounds from locations not known to be polluted with toluene. However, an ubiquitous presence of biogenically formed toluene in anaerobic habitats as reported for anoxic hypolimnions of eutrophic lakes (Jüttner and Henatsch 1986; Jüttner 1990) might explain this widespread ability of microorganisms to degrade toluene. Based on our empirical data it seems that the ability of microorganisms to grow on a specific compound may strongly depend on the conditions of cultivation in the laboratory. Critical aspects seem to be: i) toxicity of the substrate: addition of more than $2 \mathrm{mM}$ toluene inhibited growth of the bacteria (data not shown); ii) toxicity of intermediately formed nitrite during nitrate reduction; iii) $\mathrm{pH}$ dependence of toluene degradation (at $\mathrm{pH}$ values below 7.4 cells of strain $\mathrm{T}$ did not start growing on toluene, although in growing cultures the $\mathrm{pH}$ value could be lowered to 6.9 without affecting growth; data not shown).

To date, the mechanism of anaerobic toluene degradation is largely unknown. Potential pathways have been suggested by several groups (Grbić-Galić and Vogel 1987; Kuhn et al. 1988; Tschech and Fuchs 1989; Lovley and Lonergan 1990; Schnell and Schink 1991; Fig. 1): i) hydroxylation of the aromatic ring to form $p$-cresol which subsequently is oxidized to $p$-hydroxybenzoate; ii) oxidation of the methyl group to form benzoate; iii) car- boxylation of the aromatic ring. However these suggestions have to be evaluated with care. Grbić-Galić and Vogel (1987) detected traces of $p$-cresol as well as benzylalcohol in mixed methanogenic cultures; Kuhn et al. (1988) and Lovley and Lonergan (1990) based their suggestions primarily on growth and degradation experiments and not on direct identification of intermediates. Initial carboxylation of the aromatic ring was only shown for the anaerobic degradation of phenol or aniline (Tschech and Fuchs 1989; Schnell and Schink 1991), but not for toluene.

$p$-Hydroxybenzoate was transiently accumulated in growing cultures of strain T and strain K 172 and cell suspensions of strain $\mathrm{T}$ incubated with $p$-cresol (data not shown), while no intermediates were found with toluene as substrate. Similar observations have been reported recently by Lovley and Lonergan (1990) and Evans et al. (1991 b) for growing cultures. These observations suggest initial oxidation of the methyl group.

Degradation studies using fluoroacetate confirmed this hypothesis: benzoate was clearly identified as intermediate of the anaerobic degradation of toluene. Controls with $p$-cresol yielded $p$-hydroxybenzoate and small amounts of benzoate in the case of strain K 172. The formation of benzoate was probably due to dehydroxylation of $p$-hydroxybenzoyl-CoA and hydrolysis of the thioester bond. Reductive dehydroxylation of $p$-hydroxybenzoyl-CoA to benzoyl-CoA and high thioesterase activities have been shown for strain K 172 and several other Pseudomonas strains (Glöckler et al. 1989; Dangel et al. 1991; Seyfried et al., in preparation).

Suspensions of toluene-grown cells of strain $\mathrm{T}$ and strain K 172 were not able to degrade benzylalcohol although strain $\mathrm{K} 172$ was able to grow on $1 \mathrm{mM}$ benzylalcohol. Probably benzylalcohol is not a free intermediate. A similar observation was reported recently for p-cresol-degradation by sulfate-reducing enrichment cultures (Smolenski and Suflita 1987).

Growing cultures and cell suspensions of strain $\mathrm{T}$ and strain K 172 never accumulated benzaldehyde. This was probably due to the high activity of benzaldehyde-dehydrogenase. A high activity of this enzyme in crude extracts of strain K 172 was also reported by Dangel et al. (1991).

Initial carboxylation of toluene to toluate can be excluded for strain $\mathrm{T}$ and strain $\mathrm{K} 172$ since no ${ }^{14} \mathrm{CO}_{2}$ was incorporated into the molecule and the carboxyl group of benzoate was fully derived from the methyl side chain of toluene.

We therefore conclude that the initial catabolic step of anaerobic degradation of toluene is the oxidation of the methyl group to benzoate and not initial hydroxylations or carboxylations of the aromatic nucleus.

Acknowledgements. We thank Judith Perlinger and Noel Urban for reviewing the manuscript. This project was supported by grants from Ciba-Geigy Ltd. and the European Communities (Project COST 641).

\section{References}

Dangel W, Brackmann R, Lack A, Magdy M, Koch J, Oswald B, Seyfried B, Tschech A, Fuchs G (1991) Differential expression 
of enzyme activities initiating anoxic metabolism of various aromatic compounds via benzoyl-CoA. Arch Microbiol $155: 256-262$

Dolfing J, Zeyer J, Binder-Eicher P, Schwarzenbach RP (1990) Isolation and characterization of a bacterium that mineralizes toluene in the absence of molecular oxygene. Arch Microbiol 154:336-341

Evans PJ, Mang DT, Young LY (1991 a) Degradation of toluene and $m$-xylene and transformation of $o$-xylene by denitrifying enrichment cultures. Appl Environ Microbiol 57:450-454

Evans PJ, Mang DT, Kim KS, Young LY (1991 b) Anaerobic degradation of toluene by a denitrifying bacterium. Appl Environ Microbiol 57:1139-1145

Fishbein L (1985) An overview of environmental and toxicological aspects of aromatic hydrocarbons. II. Toluene. Sci Total Environ $42: 267-288$

Gibson DT, Subramanian V (1984) Microbial degradation of aromatic hydrocarbons. In: Gibson DT (ed) Microbial degradation of organic compounds. Marcel Dekker, New York, pp 181 252

Glöckler R, Tschech A, Fuchs G (1989) Reductive dehydroxylation of $p$-hydroxybenzoyl-CoA to benzoyl-CoA in a denitrifying, phenol-degrading Pseudomonas species. FEBS Lett 251:237240

Grbić-Galić D, Vogel TM (1987) Transformation of toluene and benzene by mixed methanogenic cultures. Appl Environ Microbiol 53:254-260

Herbert D, Phipps PJ, Strange RE (1971) Determination of protein with the Folin-Ciocalteau reagent. In: Norris JR, Ribbons DW (eds) Methods in microbiology, vol. 5B. Academic Press, London New York, pp 249-252

Jüttner F (1990) Distribution of toluene in stratified lakes and river dams of Southwest Germany. Verh Int Verein Limnol 24:279 281
Jüttner F, Henatsch JJ (1986) Anoxic hypolimnion is a significant source of biogenic toluene. Nature 323:797-798

Kuhn EP, Colberg PJ, Schnoor JL, Wanner O, Zehnder AJB, Schwarzenbach RP (1985) Microbial transformations of substituted benzenes during infiltration of river water to groundwater: laboratory column studies. Environ Sci Technol 19:961-968

Kuhn EP, Zeyer J, Eicher P, Schwarzenbach RP (1988) Anaerobic degradation of alkylated benzenes in denitrifying laboratory aquifer columns. Appl Environ Microbiol 54:490-496

Lovley RD, Lonergan DJ (1990) Anaerobic oxidation of toluene, phenol and $p$-cresol by the dissimilatory iron-reducing organisms, GS-15. Appl Environ Microbiol 56:1858 - 1864

Schnell S, Schink B (1991) Anaerobic aniline degradation via reductive deamination of 4-aminobenzoyl-CoA in Desulfobacterium anilini. Arch Microbiol 155:183-190

Seyfried B, Tschech A, Fuchs G (1991) Anaerobic degradation of phenylacetate and 4-hydroxyphenylacetate by denitrifying bacteria. Arch Microbiol 155:249-255

Smolenski WJ, Suflita JM (1987) Biodegradation of cresol isomers in anoxic aquifers. Appl Environ Microbiol 53:710-716

Tschech A, Fuchs G (1987) Anaerobic degradation of phenol by pure cultures of newly isolated denitrifying pseudomonads. Arch Microbiol 148:213-217

Tschech A, Fuchs G (1989) Anaerobic degradation of phenol via carboxylation to 4-hydroxybenzoate: in vitro study of isotope exchange between ${ }^{14} \mathrm{CO}_{2}$ and 4-hydroxybenzoate. Arch Microbiol 152:594-599

Wilson BH, Smith GB, Rees JF (1986) Biotransformations of selected alkylbenzenes and halogenated aliphatic hydrocarbons in methanogenic aquifer material: a microcosm study. Environ Sci Technol 20:997-1002

Zeyer J, Kuhn EP, Schwarzenbach RP (1986) Rapid microbial mineralization of toluene and 1,3-dimethylbenzene in the absence of molecular oxygen. Appl Env Microbiol 52:944-947 